\title{
Serialization of Ọbasa's Poems in The Yorùbá News
}

Tolulope Ibikunle

Department of Linguistics and African Languages

University of Ibadan, Nigeria

toluwanimiibikunle@gmail.com

\begin{abstract}
Every newspaper has its form, structure, and pattern. The Yorùbá News published between 1924-1945 was not an exception, as it comprised of different contents ranging from the editorial opinion to home news, gossip, adverts, and serialization of different forms of narratives. D.A. Obasa, the publisher of The Yorùbá News, also published many works of poetry. Obasa started the publication of excerpts of his poems in The Yoruba News under the column "Àwọn Akéwì." Serializing these poems, therefore, means issuing them regularly and consecutively in different editions of the newspaper. In the various scholarly engagements with Obasa's works, little or no attention has been given to the serialization of his poems in The Yorùbá News. The focus of this easy therefore is to fill this gap by highlighting and documenting the serialized poems of Obasa in The Yorùbá News. Through intertextuality theory, the easy aims at appraising how Obasa transfer his knowledge of the Yorùbá oral literature to his readers through his application of oral poetic form from his serialized poems. This work will therefore dwell on Intertextuality and its influence on the works of Obasa, which will enable us to discuss his creative ability as a cultural activist.
\end{abstract}

\section{Introduction}

Communication is the means of disseminating information within the society, which makes information agencies crucial to the growth of any society. In the traditional Yoruba society, information is disseminated through recognized officials, recognizable sounds, sign, and symbols. It is in this light that Omu (1978) argues that, "Indigenous Nigerian society had no newspaper, but had agencies and institutions which in several respects served the same 
purposes as the modern-day information dissemination facilities" (1). Some of these modern information facilities are television, radio, social media, and the print media. Language is very important to information dissemination, as it is the means of communication; written, speaking, sign, foreign or local languages. It is the targeted readers of any publication that determine its language mode and content. This is applicable to The Yorùbá News newspapers, as the targeted readers determine the language use and even the content. The Yorùbá News is a bi-lingual newspaper, with Yorùbá as the primary language and English as secondary, as it is written for Yorùbá speakers of the southwestern region of Nigeria where English is the second language. Since the readers determine the language and content of any publication, different cultural beliefs, tradition, philosophy and even literature of the targeted readers, always reflect in the publication meant for such readers.

This paper starts with a discussion on the rise of newspaper publication in Nigeria. The language of any newspaper determines its circulation and it goes a long way in connecting with the speakers of such language. It is in this light that Akínyemi (2017) claims, "Obasa's choice of Yoruba language for his writing assisted him to connect with the generality of the people in his locality" (11). The content of the newspaper, therefore, covers the entire nation, with a special focus on its locale. Some of the regular sections of the newspaper are news, advertisement, and serialization of literary works. This essay therefore identifies and documents Obasa's poems serialized in the newspaper. To achieve this, the essay dwells on intertextuality in its evaluation of Obasa's serialized poems.

\section{The Yorùbá News Newspaper}

A newspaper is a serial publication that contains news about current events and other informative articles on politics, sports, arts, culture, and advertisement. Newspapers are variable tools of information dissemination. To realize this, newspaper contains different sections that inform the public of important events around the world and their locale. It is in this light that we have different indigenous newspapers, which are written for the benefit of different indigenous language speakers. The first newspaper in Nigeria is the İwe Iroyì fưn Àwọn Ará Ègbá àti Yorùbá edited by Henry Townsend who arrived Abeokuta in the 1850s and established a printing press in 1854. The main purpose of this newspaper was to teach new converts to Christianity how to read and write, and gradually developed their reading habit. This implies that newspaper can serve different purposes for different publishers and readers.

After İwé Iroyì fún Àwọn Ará Ègbá àti Yorùbá, other newspapers were published in Yorùbá and English language, with different targeted readers, 
focus, and content. Some of these publications are Daily Times of Nigeria, (1925), Tribune (1949), The Punch (1971), Observer (1968), The Tide (1971), Vanguard (1983), Guardian (1983), Newswatch (1985), and even Yorùbá newspapers like Alároyé (1985), Akéde È kó, Akéde Àgbáyé and İròì Òwúrọ. The Yorùbá News, which was published by Ilare Printing Press between 1924 and 1945 is not out of the list. According to Akínyemi (2017), "with the opening of Obasa's Ilare Printing Press in Ibadan, the company was able to draw patronages not only from the city of Ibadan but also from many other Yoru bá cities such as Osogbo, Ile-Ife, Iwo, Oyo, Ilesa, Ekiti, etc. The press flourished and became well-known in many Yorùbá communities and homes" (10). This implies that the newspaper was written largely for Yorùbá native speaker/readers, while the content covers the entire nation, with special focus on the Yorùbá locale. The Yorùbá News is a weekly publication, published and edited by Obasa, a poet, and promoter of Yorùbá language and indigenous knowledge system. For these reason, the publication always demonstrates the cultural, philosophical, and socio-political commitment of the publisher and editor to the Yorùbá language, culture, and tradition.

\section{Serialization of Literature in Media}

Serialization is a means by which a single large work is published in sequence before, or after the publication or production of the whole work. The serialization of works of narrative fiction (prose, poetry or drama) occur in different media forms; television, radio and newspaper. The most prominent form of serialization is on television and radio, with a serial of continuing plot that unfolds in a sequential episode. This form of serialization is known as Soap Opera on television, which originates from the radio. Some serialized programs on Yorùbá radio are "Lábẹ Ộrun", "Abulé Ọlókèmẹrin" and other weekly narration of different stories on different radio stations. Some of these radio serialized stories have been adapted into television series by different director and producer. This also is evident in productions such as "Arelu" by Jimoh Aliu, "Kóotu Așípa" by Oyin Adejọbi, "Àwàdà Kẹrí kẹri” by Òjó Ládipọ and several others on different television stations.

In the print media, different authors and poets serialized their prose, drama, and poetry. Sometimes, the serialization in newspaper comes before the publication of the actual work. This is evident in the serialization of "Itan èmi Șẹgí lolá" by I.B. Thomas in Akéde E kó newspaper, which was later published as the first Yoruba novel under the same time (Barber 2012). It is in this regard that Obasa serialized his poems in the weekly Yorùbá News publication before their eventual publication in his trilogy. Hence, the serialization of any literary work promotes the major work. This implies that serialization can be 
used as a means of "testing the water" and publicizing a literary work, before or after its publication. This is evident in different newspapers, television stations, and radio stations, where different artist serialized their literary works. Also, serialization of any literary work gives the producer, writer, author, poet, and director instant feedback on their artistries, which can initiate the eventual publication of the major work.

\section{Serialization of Obasa's poems in The Yorùbá News}

Obasa published the first issue of his weekly newspaper The Yoruba News on January 15, 1924. This publication reported different local news and issues in different towns of the Yorubaland. According to Akinyemi (2017), "On February 12, 1924, Obasa started what became a regular feature: the publication of excerpts of his poems in the Yoruba News under the column 'Àwọn Akéwì"' (12). He writes his poems in Yorùbá in order to be able to address his immediate local audience. Hence, Akinyemi (2017) opines, "One can say that, by far, the greatest influence on Obasa was his love for, and interest in Yoruba language, oral literature and folklore, tradition, and cultural practices" (11).

The serialization of Obasa's poems under the column "Àwọn Akéwì", is a major form of serialization in the weekly publication. Also, Obasa serialized different ori ki and stories of some selected Yorùbá towns and diverse topics in the Yorùbá culture. The serialization of Obasa's poems started on February 12, 1924 with the poem "Iku'" and ended on September 1, 1942 with "Àsẹ Ibísi". Also, the first orí ki serialized is "Orí ki Ẹgé (Gbáguda)" on March 18, 1924 and the last is "Orí ki 'Oge" on June 2, 1942. The contents of these forms of serialization in The Yorùbá News depict different aspect of the Yorùbá worldview on diverse topics.

Three years into the serialization of his poems, Obasa published his first anthology titled İwé Kíní ti Àwọn Akéwì (Yorùbá Philosophy), with a total of twenty-nine (29) poems in 1927. Seven years after, he published another titled İwé Kejì ti Àwọn Akéwì (Yorùbá Philosophy) in 1934 with a total of thirty-nine (39) poems. By 1945, Obasa published his third book and also titled it İwé Kẹta ti Àwọn Akéwì (Yorùbá Philosophy) with a total of thirty-one (31) poems. In all, he published a total of 99 (ninety-nine) poems in his three books. In sum, between 1924 and 1942, Obasa serialized his poems in the newspaper, while between 1927 and 1945, he published the three books of his poems. Our archival research shows that Obasa published one hundred (100) poems in ninety-nine (99) editions of The Yorùbá News.

It is also important to add that Obasa serialized twenty different ori $k i$ of different people, towns, and villages. Likewise, different important tribes, food, and tradition of the Yorùbá were published in the newspaper. This essay 
identifies twenty-one editions (weeks) of this serialized ori ki and eulogy on diverse topics. The first chart below summarizes the title of poems published in The Yoruba News, date of their publication, and the particular book Obasa published each of the poems in. The second chart illustrates the names of poems not serialized in The Yorùbá News but published in the books, while the chart also includes the specific book of the publication. The third chart is on the title of the ori ki published in The Yoruba News and the date of publication of each ori ki in The Yoruba News. This illustration implies that not all the poems serialized in The Yorùbá News were published in Obasa's books; and not all poems published in his Àwon Akéwi I, II \& III were serialized in the newspaper. Hence the chart also illustrates the frequency of the serialization of the poems in The Yorùbá News:

\begin{tabular}{|c|c|c|c|}
\hline S/No & $\begin{array}{l}\text { Title of poem pub- } \\
\text { lished in The Yoruba } \\
\text { News }\end{array}$ & $\begin{array}{l}\text { Date of publication of each } \\
\text { poem in The Yoruba News }\end{array}$ & $\begin{array}{l}\text { Book Published in } \\
\text { eventually }\end{array}$ \\
\hline 1. & Ikú & February 12, 1924 & İwé Keji \\
\hline 2. & Òrun & February 26, 1924 & Not Published \\
\hline 3. & Ilé & March 4, 1924 & İwé Kejì İwé kẹta \\
\hline 4 & Fálànà & March 4, 1924 & \\
\hline 5. & Pẹ̉lẹ́pẹ̀lẹ́ & $\begin{array}{l}\text { March } 251924 \text { (republished } \\
\text { September } 15 \text { - } 221925\end{array}$ & İwé kínní \\
\hline 6. & Mọ́kánjúọlá & March 251924 & İwé kínní \\
\hline 7. & Ėrè-Ișé & $\begin{array}{l}\text { April } 11924 \text { (republished } \\
\text { on July } 27 \text { 1926) } \\
\end{array}$ & $\begin{array}{l}\text { İwé kínnílìwé } \\
\text { Keji }\end{array}$ \\
\hline 8. & Elétò-Ētò & $\begin{array}{l}\text { April } 81924 \text { (republished } \\
\text { on July } 27 \text { 1926) }\end{array}$ & İwé kínní \\
\hline 9. & Aláigbọràn & April 151924 & İwé kinní \\
\hline 10. & Aláṣejù & $\begin{array}{l}\text { April } 151924 \text { (republished } \\
\text { on April } 221924 \text { and April } \\
291924\end{array}$ & İwé kínní \\
\hline 11. & Àgbèrè & May 51924 & İwé kínní \\
\hline 12. & Ogboọ́n Àgbọ́njù & May 131924 & İwé kínní \\
\hline 13 & Ërin & May 20, 1924 & İwé kẹta \\
\hline 14. & İlara & May 271924 & İwé kínní \\
\hline 15. & Ọmọ & June 3,1924 & $\begin{array}{l}\text { İwé kínni/ İwé } \\
\text { Keji }\end{array}$ \\
\hline
\end{tabular}


Tolulope Ibikunle

\begin{tabular}{|c|c|c|c|}
\hline 16. & Orin Agónnigàn & June 10,1924 & İwé Keji \\
\hline 17. & Bàbá & June 10,1924 & İwé Keji \\
\hline 18. & Eérú & June 17,1924 & İwé Kejil İwé kẹta \\
\hline 19. & İkà-Èké & June 241924 & İwé kínní \\
\hline 20. & Ộpẹlẹ́ngé & July 1, 1924 & İwé kẹta \\
\hline 21. & Ẹwà & July 1, 1924 & İwé kẹta \\
\hline 22. & Arẹwà & July 1, 1924 & İwé kẹta \\
\hline 23. & Tẹnimẹyìn & July 8,1924 & İwé Keji \\
\hline 24. & İfẹ́ Ètè & July 8, 1924 & İwé Keji \\
\hline 25 & Ọ̀rọ̀ Ẹihin & July 8, 1924 & İwé Keji \\
\hline 26. & Ẹyẹ & July 151924 & İwé kínní \\
\hline 27. & İtànjẹ & July 151924 & İwé kínní \\
\hline 28. & Àidọgba & July 151924 & İwé kínní \\
\hline 29. & Èdá & $\begin{array}{l}\text { August } 51924 \text { (republished } \\
\text { on September } 14 \text { 1926) }\end{array}$ & İwé kínni \\
\hline 30. & Ogbọ́n & $\begin{array}{l}\text { August } 51924 \text { (republished } \\
\text { on September } 14 \text { 1926) }\end{array}$ & İwé kínní \\
\hline 31. & Obinrin & August 19, 1924 & İwé kẹta \\
\hline 32. & Ẹta-n'ta-gbá & August 19, 1924 & İwé kẹta \\
\hline 33 & Ọ̀lẹ & $\begin{array}{l}\text { August } 261924 \text { (repub- } \\
\text { lished on November } 23 \\
1926 \text { and November } 30 \\
1926\end{array}$ & İwé kínní \\
\hline 34 & İkíni & September 21924 & İwé kínní \\
\hline 35 & Oore & September 91924 & İwé kínní \\
\hline 36 & Òtitọ́ & October 21,1924 & İwé Keji \\
\hline 37 & Àwọn Ejò & November 4, 1924 & İwé kẹta \\
\hline 38 & İtàn Tápa àti Yorùbá & November $11 \& 181924$ & İwé kẹta \\
\hline 39 & İlú İlọrin & December 25, 1924 & İwé kẹta \\
\hline 40 & Iriri & February 3, 1925 & İwé Kejì \\
\hline 41 & Ahun & February 3, 1925 & İwé Keji \\
\hline 42 & Ebi & February 17, 1925 & İwé Keji \\
\hline 43 & Awurelà & February 24, 1925 & İwé kẹta \\
\hline 44 & İyàn Yánmọroro & March 31925 & İwé kínní \\
\hline
\end{tabular}




\begin{tabular}{|c|c|c|c|}
\hline 45 & Ọ̀rọ̀ Burúkú & August 18, 1925 & İwé kẹta \\
\hline 46 & Pẹlệpẹllẹ & September $15-221925$ & İwé kinní \\
\hline 47 & Olówó & September 29,1925 & İwé kẹta \\
\hline 48 & Ọ̀kánjúwà & October 6, 1925 & \\
\hline 49 & Ọ̀kánjúwà-Olè & November 3-10, 1925 & İwé Keji \\
\hline 50 & İwà & November 24, 1925 & İwé Keji \\
\hline 51 & Oní jọngbọ̀n & December 1, 1925 & İwé kẹta \\
\hline 52 & Arígbọdộwí & December $15-22,1925$ & İwé Kejì \\
\hline 53 & Agọ́nnigàn II & December 29, 1925 & İwé Kejil İwé kẹta \\
\hline 54 & Wộbìà & February 23, 1926 & İwé kẹta \\
\hline 55 & Ọtí & March 23, 1926 & İwé kẹta \\
\hline 56 & İwàwara & March 30, 1926 & İwé kẹta \\
\hline 57 & Ète & April 27, 1926 & İwé kínní \\
\hline 58 & Adámálesse & May 4, 1926 & İwé kẹta \\
\hline 59 & Àtara-ẹni-rò & July 6-13, 1926 & İwé kínní \\
\hline 60 & Kí la ti máa șe é? & July 201926 & İwé kínní \\
\hline 61 & Elétò-Ètò & July 27, 1926 & İwé kínní \\
\hline 62 & Ėrè-Ișẹ & July 27, 1926 & İwé kínní \\
\hline 63 & Aiyé Ọ̀dájú & August 3-10, 1926 & İwé kínní \\
\hline 64 & Oníwọ̀ra & August 3-10, 1926 & İwé kínní \\
\hline 65 & İbàjẹ́ & August 3-10, 1926 & İwé kínní \\
\hline 66 & Ẹdá & September 141926 & İwé kínní \\
\hline 67 & Ogbọ́ Àgbọ́jù & $\begin{array}{l}\text { October } 12 \text {-November } 16 \\
1926\end{array}$ & İwé kínní \\
\hline 68 & Ọ̀lẹ & November 23-30, 1926 & İwé kínní \\
\hline 69 & Ebi & November 23-39, 1926 & İwé kínní \\
\hline 70 & Àwí-ìgbọ́ & November 3, 1931 & İwé Keji \\
\hline 71 & Oníwọra & November 17, 1931 & İwé kínní \\
\hline 72 & Ẹẹrù & November 24,1931 & İwé kẹta \\
\hline 73 & Owó-Ajé & January 5-12 1932 & İwé kẹta \\
\hline 74 & Àgbékà ợọ̣ & June 26,1932 & Not published \\
\hline 75 & $\begin{array}{l}\text { İrẹjẹ tảbi ogbufọ̀ kéwú } \\
\text { İbàdàn }\end{array}$ & December 30, 1934 & İwé kẹta \\
\hline 76 & İwọ̀n-Tun-Wọn-Sì & August 8-15, 1939 & Not published \\
\hline
\end{tabular}




\begin{tabular}{|c|c|c|c|}
\hline 77 & Ogun, Orin Agánigàn & August 29, 1939 & İwé Keji \\
\hline 78 & Ẹmu & September 19-26 1939 & Not published \\
\hline 79 & İjálá & October 31, 1939 & Not published \\
\hline 80 & Àgbà & February 13, 1940 & Not published \\
\hline 81 & Kiriyó & March 5, 1940 & Not published \\
\hline 82 & Má Gbẹsan & March12, 1940 & Not published \\
\hline 83 & Àșeșá-Àșetẹ & June, $18-251940$ & Not published \\
\hline 84 & Ogbe-Dájú & September 1940 & Not published \\
\hline 85 & Àșesá & November 5-12, 1940 & Not published \\
\hline 86 & Tójú- İwà II & November 5-12, 1940 & Not published \\
\hline 87 & Gbe-Tìrẹ & November 9, 1940 & Not published \\
\hline 88 & Gbọ́-Tirẹ & November 19, 1940 & Not published \\
\hline 89 & Elewu- Ewu & November 26, 1940 & Not published \\
\hline 90 & Òtoṣi & November 26, 1940 & Not published \\
\hline 91 & İrọra & November 26, 1940 & Not published \\
\hline 92 & Bọ́lugi & February 24, 1942 & Not published \\
\hline 93 & ó do ó di & March 3, 1942 & İwé kẹta \\
\hline 94 & Máa j Èvà & May 19, 1942 & Not published \\
\hline 95 & Ëèmọ & June 2, 1942 & Not published \\
\hline 96 & Iku & June 9, 1942 & İwé Kẹta \\
\hline 97 & İyà l'órí İyà & June 23, 1942 & Not published \\
\hline 98 & Fộrọlọ & June 23, 1942 & Not published \\
\hline 99 & Iyọ di Ji bì tì & June 30, 1942 & Not published \\
\hline 100 & Àsẹ i bísí & September 1,1942 & Not published \\
\hline
\end{tabular}

Chart 1: Frequency of the Serialization of the Obasa's Poems in The Yorùbá News

On cross-checking the serialized poems above with Obasa's published trilogy, it is evident that there are some poems published in the books that are not serialized in the newspaper. Hence, this essay highlights these poems in order to be able to have detailed documentation of all the poems of Obasa in the books and newspaper. 


\begin{tabular}{|c|c|c|}
\hline S/NO & $\begin{array}{l}\text { Title of poem not published in The } \\
\text { Yorùbá news }\end{array}$ & Book published in \\
\hline 1 & Pagidarì & İwé Kinní \\
\hline 2 & İyàn Ẹlẹ́fẹé & İwé Kinní \\
\hline 3 & İfẹràn & İwé Kejì \\
\hline 4 & Irọ́ & İwé Keji \\
\hline 5 & Àșejù & İwé Kejì \\
\hline 6 & Ọ̀kín & İwé Keji \\
\hline 7 & Onímọle & İwé Kejì \\
\hline 8 & Àntí Onílà & İwé Keji \\
\hline 9 & Ọmọ oní lẹ & İwé Keji \\
\hline 10 & Àyí dà Aiyé & İwé Keji \\
\hline 11 & Àigbọ́n & İwé Kejì \\
\hline 12 & İlù Sójà & İwé Keji \\
\hline 13 & Oní jẹkú jẹ & İwé Keji \\
\hline 14 & Elẹ́nu méjì & İwé Keji \\
\hline 15 & Àșejù & İwé Kejì \\
\hline 16 & Òmùgọ & İwé Keji \\
\hline 17 & Ọbẹ-Ẹran & İwé Keji \\
\hline 18 & Ọ̀wọn N'lá & İwé Keji \\
\hline 19 & Ojú ko fẹ́rakù & İwé Keji \\
\hline 20 & Ẹni Ộwọ̀ & İwé Keji \\
\hline 21 & Òbúrẹwà & İwé kẹta \\
\hline 22 & İwàràpapa & İwé kẹta \\
\hline 23 & Ológbojo & İwé kẹta \\
\hline 24 & Ọlọ́pọndà & İwé kẹta \\
\hline 25 & Odún tuntun & İwé kẹta \\
\hline 26 & İgbà Òibó & İwé kẹta \\
\hline 27 & Àdá & İwé kẹta \\
\hline 28 & İnagijẹ tàbí Àpèjá Erin & İwé kẹta \\
\hline
\end{tabular}

\section{Chart 2: Chart 1: Ọbasa's Poems not Serialized in The Yorùbá News before Publication in his Trilogy}

As one of the earliest poets and newspaper editor, Obasa utilized the Yorùbá communal oral resources to the fullest. Through his newspaper - The Yorùbá News - Obasa escalates the social and cultural consciousness of his readers through his poetic composition in the newspaper. Aside the serialized 
poems, there are also some other excerpts from Obasa's collection of ori ki ori lẹ and other poems, under the column the "Oríki ti Àwọn ilẹ Yorùbá" and also "Àwon Akéwi." Some of these serialized ori ki and other works with their date of publication are:

\begin{tabular}{|c|c|c|}
\hline S/No & $\begin{array}{l}\text { Title of ori ki published in } \\
\text { The Yoruba News }\end{array}$ & $\begin{array}{l}\text { Date of publication of each ori ki in The } \\
\text { Yoruba News }\end{array}$ \\
\hline 1. & Oríki Ègé (Gbáguda) & March 18, 1924 \\
\hline 2. & İtàn Tápa àti Yorùbá & November 11 \& 181924 \\
\hline 3. & İtà Tápa àti Yorùbá & December 2, 1924 \\
\hline 4. & Ìlú İlọrin & December 25, 1924 \\
\hline 5. & Oríki Oyèwọlé & July 28, 1925 \\
\hline 6. & Clerkship by Ben N Azikwe & Dec 1, 1925 \\
\hline 7. & Oríki İkoyí & February 9, 1926 \\
\hline 8. & $\begin{array}{l}\text { İtàn Tápà àti Yorùbá } \\
\text { (Ológbojo') }\end{array}$ & February 23, 1926 \\
\hline 10 & Ègbá & December 21- 281926 \\
\hline 10 & Oriki Tìmí Ọba Ẹdẹ & December 21- 281926 \\
\hline 11. & İlù oșugbó & June 21-28 1932 \\
\hline 12. & $\begin{array}{l}\text { İrẹjẹ tàbi ogbufọ̀ kéwú } \\
\text { İbàdàn }\end{array}$ & December 30, 1934 \\
\hline 13. & Ègé & August 22, 1939 \\
\hline 14. & Orin: Hilter Misita Hita & November 21, 1939 \\
\hline 15. & Àdúrà Ọdún & January 16-23 1940 \\
\hline 16. & Olúfọ́n & April 28, 1942 \\
\hline 17. & Oríkì Opó & May 26, 1942 \\
\hline 18. & Oríkì Ògún & June 2, 1942 \\
\hline 19. & Oríki Oge & June 2, 1942 \\
\hline
\end{tabular}

Chart 3: Serialized Yoruba praise poetry (ori ki) in The Yorùbá News

These poems constitute the reflective and critical interrogation of Yorùbá culture and the full range of implication for human existence. Some are documentation of different lineage, histories, praise poetries, and other important cultural and philosophical topics in the Yorùbá society. The whole serialization of Obasa's artistry in The Yorùbá News explains that writers are visionaries that see what is going on their society and will do everything possible to have a positive influence on their society through their artistic endowment. As Akínyẹmi (2017) right suggests, Ọbasa transforms oral traditions 
into metaphorical and symbolic language that best articulates his political or philosophical positions. It is also very important to note that these poems are not just randomly selected for serialization, but some of them are serialized based on their relevance to the social situation and the content of the particular edition of the newspaper. With the interrelationship between the serialized works of Obasa and his published trilogy, it is important that this essay adopt intertextuality as a literary concept for our discussion of Obasa's works.

\section{Intertextuality as Literary concept}

The concept of intertextuality spreads across all genres of literature; drama, prose, poetry, and film. As coined by Julia Kristeva in 1986, the term intertextuality is a way of interpreting texts, which focuses on idea of texts' borrowing words and concepts from each other. Kristeva (1986) opines that, “... any text is constructed as a mosaic of quotations; any text is the absorption and transformation of another..." (37). Hence, the theory of intertextuality is preoccupied with the text and its link with other texts. Other terms used in describing the relationship between texts include allusion, parody, adaptation and influence. Hence, there are variables of culture, tradition, and philosophy that penetrates different literary artist during their artistic creation. Therefore, Adéléke' (2008) argues, "With cultural cross-fertilization, which sometimes culminates into biological intermixture of different people, values and ideas that were initially sacrosanct usually become modified" (95). Certain aspect of different culture, tradition and philosophy are therefore integrated in the recreation of different artist.

Since literature is define as either mimetic by Aristotle and Plato, and as an imitation of pre-existent texts by Kolawole (2005:8), different artists build on different material (oral or written) they are exposed to. Thus, Adélékè (2008) contends that the above submission is what Julia Kriesteva, refers to as "intertextuality". The implication is therefore that a new literary work of art cannot and will not exist independent of a literary tradition, as the proto-literary tradition will have its influence. The extent of the impact and effect of intertextuality therefore, differs, thus an artistic creation can be impacted on overtly or implicitly by other texts, ideologies, literary tradition or linguistics patterns, and belief system of a particular social milieu. Thus, Adélékè (2008) submits that cultural difference and diversity in literary traditions play vital role in intertextuality terrains.

Intertextuality is therefore the structuring of a text's meaning by another text. It is the interconnection between similar or related works of literature that reflect and influence an audience's interpretation of the text. Intertextuality is a literary device that creates an interrelationship between texts 
and generates related understanding in separate works (Culler 1981; Machacek 2007). In this light, intertextuality denotes the way texts gain meaning through their referencing of other texts. This implies that intertextuality is a process of creating references to any form of literary work via another literary work. In other words, in literary discourse, intertextuality can occur in prose, poetry, drama, or even film. In this light, the concept aids communication, which is why Allen (2012) refers to the concept as a prominent feature of media studies, which influence studies of adaptation, interpretation, and appropriation of text into other media. Intertextuality, transposition, and appropriation are forms of adaptation, which is a regular feature of arts production that involves borrowing or reworking of part or the whole of a particular genre into a new context or form.

This concept of intertextuality is not strange in the Yorùbá literature, as some artists create a new piece of their work through an existing one, while some only extract some part of their earlier works (published or unpublished) into the new work. This may be as a result of demand from their readers or just influence from the previous work. These texts will have their intertext no matter how marginal they may seem. This is evident in Akínwùmí İsọla's creativity. İsọ̣lás creative works (prose, poetry and drama), were adapted into films by different filmmakers especially Túndé Kèlání, through different forms of adaptation. Adaptation of Issọla's works is therefore a subtle practice that involves multiple movements between genres of different types. This transformation of different genres offers unique opportunities for the circulation of Ișọlás creativity. Intertextuality in Akínwumi İsọla's' works, thus show practices that embraces a wide gamut of genres. In this light, serialization of Obasa's poems in The Yorùbá News newspaper and eventual publication in his trilogy is no doubt a perfect instance of the influence of intertextuality on literary works.

Obasa's creative ingenuity, begins with the publications of his poems in The Yorùbá news newspaper, which develops into books. Obasa used the same titled as the heading of the column in the newspaper "A'wọn Akéwi" in the title of the published trilogy. With the explanation above on Obasa's poems (serialized and published) it is evident that the degree of variation of intertextuality in his works depends largely on him and his target readers. Some published works in his trilogy are not serialized in his column in the newspaper while some were serialized but not published in any of his trilogy. Obasa compiled different Yorùbá sociocultural values to educate his readers on the benefit of good conduct in preserving socio-economic dignity of the society. This implies that Obasa uses different Yorùbá (written and oral) existing literature in his poems to lay emphasis on Yorùbá literature as a concept used 
to depict rich and varied oral traditions, such as folklore, proverbs, chants, songs and even riddles.

The form of intertextuality in the works of Ọbasa, Thomas, and İsọla' are in different appearance and degree. The three artists use different Yorùbá philosophical sayings in their works with the hope of influencing their society with their artistic endowment. İsọ la's form is wider, as he writes three different types of genre (prose, poetry and drama). Obasa concentrates more on poetry while Thomas' attention is to prose. It is in this regard that the three forms of Issọ la' genres are adapted for films by filmmakers, which enables interaction especially between his poems and stories. In the case of Obasa, it is strictly interaction between his published and serialized poems. While the interaction in Thomas' artistic endowment is in the serialized and the eventual publication as a novel. Isọla' focuses on stories, history, myth, and poetry in his artistry. His artistic endowment depicts strings of historical antecedents, stories in form of a biography, and series of imaginative compositions. For Thomas, it is in form of an actual event, which is an autobiographical write-up with strings of different events and experiences. Obasa also have poems that are assemblage of strings of traditional sayings only, combination of strings of traditional sayings and his original composition, and his own composition with hardly any traditional sayings. It is in this regard that Akinyemi (2017) summarizes the extent of oral literary material in each of the three books of poetry authored by Obasa thus:

\begin{tabular}{|l|l|l|l|l|}
\hline $\begin{array}{l}\text { Types of Obasa's } \\
\text { Poems }\end{array}$ & \multicolumn{4}{l}{$\begin{array}{l}\text { Number of poems in each book and percentile of oral literary } \\
\text { material represented therein }\end{array}$} \\
\hline & Book 1 & Book 2 & Book 3 & Books 1-3 \\
\hline $\begin{array}{l}\text { Total poems in } \\
\text { book(s) }\end{array}$ & 29 & 39 & 31 & 99 \\
\hline $\begin{array}{l}\text { Assemblage of } \\
\text { strings of tradi- } \\
\text { tional sayings only }\end{array}$ & $22(79.31 \%)$ & $29(74.36 \%)$ & $21(67.74 \%)$ & $\begin{array}{l}73 \\
(73.74 \%)\end{array}$ \\
\hline $\begin{array}{l}\text { Combination of } \\
\text { strings of tradi- } \\
\text { tional sayings and } \\
\text { Obasa's original } \\
\text { composition }\end{array}$ & $3(10.34 \%)$ & $3(7.69 \%)$ & $2(6.45 \%)$ & $8(8.08 \%)$ \\
\hline
\end{tabular}




\begin{tabular}{|l|l|l|l|l|}
\hline $\begin{array}{l}\text { Obbasa's own com- } \\
\text { position with } \\
\text { hardly any tradi- } \\
\text { tional sayings }\end{array}$ & $3(10.34 \%)$ & $7(17.95 \%)$ & $8(25.81 \%)$ & $\begin{array}{l}18 \\
(18.18 \%)\end{array}$ \\
\hline $\begin{array}{l}\text { Total of poems in } \\
\text { each book }\end{array}$ & $29(100 \%)$ & $39(100 \%)$ & $31(100 \%)$ & $99(100 \%)$ \\
\hline
\end{tabular}

Chart 4: Extent of Oral Literary Material in each of the three books of poetry authored by Obasa (courtesy of Akinyemi 2017).

\section{Conclusion}

Using the theory of sociology of literature and intertextuality, this essay has been able to restate that a substantial amount of African literature is adapted diversely from different old classical literatures. This implies that different artists are influenced by the creativity of other artists. Despite the influence, elements of their originality, style and perception are distinct and evident in their artistry. In the exploration of different artist to the world of histories, cultures, traditions, and stories, they are able to achieve diverse ideologies that have impacted their aesthetic endowment. Hence, this essay reaffirms the diverse ways that the Yorùbá oral poetic forms have influenced Obasa's artistry as a contemporary writer. It is in this regard that we conclude in this essay that Obasa achieves and updates different Yorùbá cultural, historical and social values through his creative skills. With the identification and documentation of archived poems of Obasa, serialized in The Yorùbá News, this essay has been able to restate the importance of intertextuality, modernization, and communication through the usage of the Yorùbá oral tradition in Obasa's poems. Hence, in this light, this work appraised the philosophical discourse that reflects the ideas of the Yorùbá people through the serialized works of Obasa in the print media. Analysis of these poems therefore suggests that artists, publishers, philosophers, writers and even poets play a very important role in their various societies. As a poet and editor of The Yoruba News, Obasa used the newspaper for immediacy and to reach a larger audience. Serializing his poems is therefore a great medium for him to educate his readers and at the same time influence the society positively.

\section{Reference}

Akínyẹmí, A. "D. A. Ọbasa (1879 - 1945): a Yorùbá Poet, Culture Activist and Local Intellectual in Colonial Nigeria." Africa. 87.1, (2017): 1-15. Akinyemi, A. "Adénrelé Adéètìmíkàn Obasá (1927-1945): Akéwì Aláròjinlẹ." Unpublished M.A. Thesis, University of Ife (Nigeria), 1987. 
Barber, K. Print Culture and the First Yoruba Novel. Laiden/Boston: Brill, 2012.

Falola, T. Yoruba Gurus: Indigenous Production of Knowledge in Africa. Trenton: Africa World Press, 1999.

Ọbasa, D. A. İwé Kiíní Ti Àwọn Akéwì (Yoruba Philosophy). Ibadan, Nigeria: Ilare Press, 1927.

Ọbasa, D. A. İwé Keji Ti Àwọn Akéwì (Yoruba Philosophy). Ibadan, Nigeria: Ilare Press, 1934.

Ọbasa, D. A. İwé Kẹta Ti Àwọn Akéwì (Yoruba Philosophy). Ibadan, Nigeria: Ilare Press, 1945.

Ogunsina, B. The Development of the Yoruba Novel c. 1930-1975. Ilorin, Nigeria: Gospel Faith Mission Press, 1992.

Olabimtan, A. "A Critical Survey of Yoruba Written Poetry, 1848-1948." Unpublished Ph.D. Dissertation, University of Lagos, Nigeria, 1974.

Olatunji, O. Features of Yoruba Oral Poetry. Ibadan, Nigeria: University Press Limited, 1984.

Omu, F. I. A. Press and politics in Nigeria 1880 - 1937. Lagos, Longman, 1978. Wilcog, D. Mass Media in Black Africa. New York: Praeger Publishers, 1975. 